\title{
Penilaian Indeks Kesehatan Terumbu Karang di TWP Selat Bunga Laut, Kabupaten Kepulauan Mentawai
}

\section{Suparno ${ }^{*}$, Yempita Efendi1, Arlius'1, Mas Eriza'1, Bukhari1, Samsuardi2, Yennafri2, M. Yaser Arafat ${ }^{3}$}

'Fakultas Perikanan dan Ilmu Kelautan, Universitas Bung Hatta Jl. Sumatera, Ulak Karang, Padang, Sumatera Barat 25133 Indonesia 2Yayasan Minang Bahari

Jl. Pekanbaru No 11, Astratek, Ulak Karang, Padang, Sumatera Barat 25133 Indonesia 3Lembaga Sertifikasi Profesi, Pusat Penelitian Oseanografi, Lembaga Ilmu Pengetahuan Indonesia Jl. Pasir Putih I, Ancol Timur, Jakartal 4430 Indonesia Email : suparnopranoto@bunghatta.ac.id

\begin{abstract}
Assessment of Coral Reef Health Index at TWP Selat Bunga Laut, Mentawai Island District

Coral reefs condition in the protected marine area at Selat Bunga has decreased every year. The health of coral reefs is represented by coral index health. The purpose of this study was to analyze the coral reefs health index based on the condition of live coral cover, resilience level and condition of coral fish. Retrieval of coral reefs data using the Under Photo Transect Method and coral fish data collection using the Under Water Visual Census. The results of research at 9 research stations found that the average cover of live coral ranged from $1.40-44.68 \%$, fleshy seaweed ranged from $0.13 \%$ $12.87 \%$, rubble ranged from $1.73-39.40 \%$, and average total reef fish biomass ranged from 8.93 $253.23 \mathrm{~kg} / \mathrm{ha}$. Coral reef health index values range between 3-6. Coral reefs health index of $67 \%$ of research stations is 3 . The coral health index value 3 is indicated by a low percent live coral cover, a high resilience rate, and a low reef fish biomass.
\end{abstract}

Keywords: Index, health, coral reefs. TWP Selat Bunga Laut

\begin{abstract}
Abstrak
Kondisi terumbu karang di Kawasan Konservasi Taman Wisata Perairan (TWP) Selat Bunga Laut telah mengalami penurunan setiap tahun. Indeks kesehatan karang adalah nilai yang mengambarkan kesehatan karang antar lokasi penelitian. Tujuan penelitian ini adalah menganalisis indeks kesehatan terumbu karang berdasarkan kondisi tutupan karang hidup, tingkat resiliensi dan kondisi ikan karang. Pengambilan data terumbu karang dengan metode Under Photo Transect dan pengambilan data ikan karang mengunakan Under Water Visual Census. Hasil penelitian di 9 stasiun penelitian didapatkan persen rata-rata tutupan karang hidup berkisar $1.40-44.68 \%$, fleshy seaweed berkisar $0.13 \%-12.87 \%$, pecahan karang berkisar $1.73-39.40 \%$, dan rata-rata total biomassa ikan karang berkisar $8.93-253.23 \mathrm{~kg} / \mathrm{ha}$. Nilai indeks kesehatan terumbu karang berkisar antara 3-6. Sebanyak $67 \%$ stasiun penelitian mempunyai indeks kesehatan terumbu karang dengan skala 3 . Indeks kesehatan karang skala 3 ditunjukkan oleh persen tutupan karang hidup yang rendah, tingkat resiliensi yang tinggi dan biomassa ikan yang rendah.
\end{abstract}

Kata kunci: Indeks; kesehatan; terumbu karang; TWP Selat Bunga Laut

\section{PENDAHULUAN}

Kawasan Konservasi Taman Wisata Perairan (TWP) Selat Bunga Laut terletak di
Kecamatan Sipora Utara dan Kecamatan Siberut Barat Daya, Kabupaten Kepulauan Mentawai, Provinsi Sumatera Barat. Dasar hukum pembentukan kawasan konservasi 
perairan ini adalah surat Keputusan pencadangan kawasan konservasi dari Gubernur Sumatera Barat No 523.6-150-2017 tentang Pencadangan Kawasan Konservasi Perairan Sumatera Barat dan Keputusan Menteri Kelautan dan Perikanan No 22 Tahun 2018 tentang Kawasan Konservasi Perairan Selat Bunga Laut. TWP Selat Bunga meliputi wilayah perairan Kecamatan Siberut Barat Daya dan perairan Kecamatan Sipora Utara. Berdasarkan Keputusan Menteri Kelautan dan Perikanan bahwa luas total TWP Selat Bunga Laut adalah 129. $566 \mathrm{Ha}$ yang terbagi atas zona inti, zona perikanan berkelanjutan, zona pemanfaatan dan zona lainnya. Pengelolaan kawasan konservasi ini diarahkan untuk perlindungan mangrove, terumbu karang, lamun, ikan Balong Padang dan Napoleon.

Berdasarkan peta habitat sebaran laut dangkal di TWP Selat Bunga Laut dijelaskan luas terumbu karang $34.05 \mathrm{~km}^{2}$ (Abrar, 2016). Penelitian LIPI tentang kondisi terumbu karang di TWP Selat Bunga Laut sejak tahun 2014 terus mengalami penurunan. Persen tutupan karang hidup tahun 2014 sebesar $25.67 \%$ (Siringoringo, 2014), tahun 2015 sebesar 23.36\% (Abrar, 2015), dan tahun 2016 sebesar 18.2\% (Abrar, 2016) dan tahun 2018 sebesar $15.77 \%$ (Suparno dan Efendi, 2018). Penurunan persen tutupan karang hidup ini yang besar dari tahun 2016-2018 diakibatkan oleh pemutihan karang (Coral Bleaching) pada pertengahan tahun 2016 dan peningkatan jumlah Acanthaster planci pada tahun 2018 (Suparno dan Efendi, 2018).

Penilaian kesehatan terumbu karang Indonesia yang telah ditetapkan Kementrian Lingkungan Hidup selama ini didasarkan pada nilai persen rata-rata tutupan karang hidup. Semakin tinggi tutupan karang hidup, semakin baik kondisi terumbu karang. Kejadian bencana alam, pencemaran perairan, penyakit karang dan perubahan iklim mengakibatkan terumbu karang Indonesia semakin hari semakin menurun, nilai indeks kesehatan karang tidak akan cocok kalau hanya didasarkan pada parameter tutupan karang hidup saja. Pada tahun 2017, Pusat Penelitian Oseanografi Indonesia LIPI telah mengembangkan indeks terumbu karang berdasarkan parameter komponen bentik untuk faktor kondisi terkini, komponen bentik untuk faktor tingkat resiliensi (potensi pemulihan) dan komponen ikan terumbu karang. Faktor kondisi terkini berdasarkan tutupan karang hidup. Faktor tingkat resiliensi terumbu karang berdasarkan tutupan fleshy seaweed (makro alga) serta tutupan pecahan karang mati (rubble) dan tutupan karang hidup). Komponen ikan karang berdasarkan biomassa ikan target meliputi 7 famili ikan yaitu famili Scaridae, Siganidae, Acanthuridae, Serranidae, Lutjanidae, Lethrinidae dan Haemulidae (Giyanto et al., 2017a).

Tujuan penelitian ini adalah menganalisis indeks kesehatan terumbu karang berdasarkan kondisi tutupan karang hidup, faktor tingkat resiliensi dan kondisi ikan karang di TWP Selat Bunga Laut.

\section{MATERI DAN METODE}

Pengambilan data terumbu karang dan ikan karang di TWP Selat Bunga Laut dilakukan 9 stasiun meliputi MTWCO1 (perairan Pulau Simakakang), MTWC02 (perairan Pulau Hawera), MTWC03 (perairan Pulau Siburu), MTWC04 (perairan Pukarayat), MTWC05 (perairan Pitojat Besar), MTWC06 (perairan Masilok), MTWC07( perairan Malilimok), MTWC08 (perairan Pulau Nyangnyang) dan MTWC09 (perairan Pulau Botik). Penelitian di lakukan pada tanggal $21-28$ April 2019.

Pengambilan data terumbu karang mengunakan metode UPT (Under Photo Transect $=$ Transek Foto Bawah Air) pada kedalaman 5 meter berdasarkan Buku Panduan Kesehatan Terumbu Karang LIPI. Transek garis yang diletakkan sepanjang 50 meter sejajar dengan garis pantai. Pengambilan data foto terumbu karang dilakukan pada frame besi dengan ukuran panjang $58 \mathrm{~cm}$ dan lebar $44 \mathrm{~cm}$. Pemotretan terumbu karang dilakukan dengan frame dengan nomor ganjil $(1,3,5, .$.$) diambil pada$ bagian sebelah kiri transek garis dan frame dengan nomor genap $(2,4,6, \ldots$.$) diambil pada$ bagian sebelah kanan transek garis (Giyanto et al., 2017b).

Pengambilan data ikan karang dengan metode Visual Sensus Bawah Air (Under Water Visual Census) berdasarkan Buku Panduan 
Kesehatan Ikan Terumbu Karang LIPI. Data ikan karang yang dikumpulkan meliputi data jenis dan kelimpahan ikan karang (ikan corallivora, herbivora dan karnivora) yang ditemukan sepanjang transek garis $70 \mathrm{~m}$ dengan batas kanan dan kiri masing-masing berjarak $2.5 \mathrm{~m}$ dengan luas area $350 \mathrm{~m}^{2}$ (Suhartini et al., 2017 ). Nilai Indeks terumbu karang dianalisis mengunakan Buku Indeks Terumbu Karang Indonesia LIPI dengan melihat parameter komponen bentik (faktor kondisi terkini dan faktor tingkat resiliensi) dan komponen ikan terumbu karang (Giyanto et al., 2017a). Komponen bentik untuk faktor kondisi karang dinyatakan oleh rata-rata tutupan karang hidup (Tabel 1).

Tabel 1. Kategori Tutupan Karang Hidup

\begin{tabular}{lll}
\hline No & Kategori & Kriteria \\
\hline 1 & Rendah & Tutupan karang hidup < \\
& & $19 \%$ \\
2 & Sedang & $\begin{array}{l}19 \% \leq \text { tutupan karang } \\
\text { hidup } \leq 35 \%\end{array}$ \\
3 & Tinggi & $\begin{array}{l}\text { Tutupan karang hidup } \geq \\
\end{array}$ \\
\end{tabular}

Sumber : Giyanto et al. (2017a)

Komponen bentik terumbu karang untuk faktor tingkat potensi pemulihan terumbu karang ditunjukkan oleh tutupan fleshy seaweed serta tutupan pecahan karang dan karang hidup secara bersamasama (Tabel 2).
Komponen ikan terumbu karang dinyatakan oleh total biomassa ikan target yang termasuk dalam 7 famili yaitu famili Scaridae, Siganidae, Acanthuridae, Serranidae, Lutjanidae, Lethrinidae dan Haemulidae (Tabel 3).

Kriteria nilai indeks kesehatan terumbu karang merupakan kombinasi komponen utama (bentik dan ikan karang), maka nilai indeks kesehatan terumbu karang akan berada dalam rentang nilai $1-10$. Nilai 10 merupakan karang yang sehat, tingkat resiliensi yang tinggi, dan habitat beberapa jenis ikan karang ekonomis penting. Nilai 1 merupakan nilai yang rendah dengan tutupan karang yang rendah, tingkat pemulihan karang yang rendah dan bukan habitat beberapa jenis ikan karang yang bernilai ekonomis penting (Tabel 4).

\section{HASIL DAN PEMBAHASAN}

Hasil penelitian komponen bentik terumbu dan substrat dasar di TWP Selat Bunga Laut dengan metode UPT didasarkan pada kondisi hard coral $(\mathrm{HC})$, recent dead coral (DC), dead coral with algae (DCA) soft coral (SC), sponge (SP), Fleshy Seaweed (FS) atau makro alga, other bioa (OT), rubble (R), sand (S), dan silt (SI) (Tabel 5). Hasil penelitian tutupan bentik terumbu karang dan substrat dasar pada sembilan (9) stasiun didapatkan tutupan karang hidup rata-rata $14.87 \%$.

Tabel 2. Kategori pada Faktor Tingkat Resiliensi (Potensi Pemulihan)

\begin{tabular}{lll}
\hline No & Kategori & \multicolumn{1}{c}{ Kriteria } \\
\hline 1 & Rendah & $\begin{array}{l}\text { (tutupan fleshy seaweed } \geq 3 \% \text { ) atau (tutupan pecahan karang }>60 \% \\
\text { dan tutupan karang hidup } \geq 5 \% \text { ) } \\
\text { (tutupan fleshy seaweed }<3 \% \text { ) atau (tutupan pecahan karang } \leq 60 \% \\
\text { dan tutupan karang hidup }>5 \%)\end{array}$ \\
\hline
\end{tabular}

Sumber: Giyanto et al. (2017a)

Tabel 3. Kategori Total Biomassa Ikan Karang

\begin{tabular}{lll}
\hline No & Kategori & \multicolumn{1}{c}{ Kriteria } \\
\hline 1 & Rendah & Total Biomassa ikan karang $<970 \mathrm{~kg} / \mathrm{ha}$ \\
2 & Sedang & $970 \mathrm{~kg} / \mathrm{ha} \leq$ Total biomassa ikan karang $\leq 1940 \mathrm{~kg} / \mathrm{ha}$ \\
3 & Tinggi & Tutupan karang hidup $>1940 \mathrm{~kg} / \mathrm{ha}$ \\
\hline
\end{tabular}

Sumber: Giyanto et al. (2017a)

Keterangan: Biomassa ikan terumbu karang $970 \mathrm{~kg} / \mathrm{ha}=33950 \mathrm{gr} / 350 \mathrm{~m}$; ; Biomassa ikan terumbu karang $1940 \mathrm{~kg} / \mathrm{ha}=67900 \mathrm{gr} / 350 \mathrm{~m}^{2}$; Luasan bidang per transek ikan terumbu karang = $350 \mathrm{~m}^{2}$ 
Tabel 4. Indeks Kesehatan Terumbu Karang

\begin{tabular}{lllll}
\hline \multirow{2}{*}{ No } & \multicolumn{2}{c}{ Komponen Bentik } & \multicolumn{1}{c}{ Komponen Ikan } & Koman \\
\cline { 2 - 4 } & $\begin{array}{c}\text { Tutupan karang } \\
\text { hidup }\end{array}$ & $\begin{array}{c}\text { Potensi Pemulihan } \\
\text { karang }\end{array}$ & $\begin{array}{c}\text { Kategori ikan terumbu } \\
\text { karang }\end{array}$ & $\begin{array}{c}\text { Indeks Kesehatan } \\
\text { Terumbu Karang }\end{array}$ \\
\hline 1 & Tinggi & Tinggi & Tinggi & 10 \\
2 & Sedang & Tinggi & Tinggi & 9 \\
3 & Tinggi & Tinggi & Sedang & 8 \\
4 & Tinggi & Rendah & Tinggi & 8 \\
5 & Sedang & Tinggi & Sedang & 7 \\
6 & Rendah & Tinggi & Tinggi & 7 \\
7 & Tinggi & Tinggi & Rendah & 6 \\
8 & Tinggi & Rendah & Sedang & 6 \\
9 & Sedang & Rendah & Tinggi & 6 \\
10 & Sedang & Tinggi & Rendah & 5 \\
11 & Rendah & Tinggi & Sedang & 5 \\
12 & Rendah & Rendah & Tinggi & 5 \\
13 & Tinggi & Rendah & Rendah & 4 \\
14 & Sedang & Rendah & Sedang & 4 \\
15 & Rendah & Tinggi & Rendah & 3 \\
16 & Rendah & Rendah & Sedang & 3 \\
17 & Sedang & Rendah & Rendah & 2 \\
18 & Rendah & Rendah & Rendah & 1 \\
\hline
\end{tabular}

Sumber: Giyanto et al. (2017a)

Substrat dasar perairan karang mati ditumbuhi algae berkisar 21.47 - $72.67 \%$ dengan ratarata tutupan $3819 \%$, dan patahan karang mati dengan tutupan rata-rata $21.71 \%$ dan dasar berpasir dengan rata-rata tutupan 13.43\%. Persen tutupan tertinggi diwakili oleh karang mati ditumbuhi algae dan diikuti patahan karang mati karena akibat peristiwa pemutihan karang tahun 2016 di TWP Selat Bunga Laut. Penelitian Abrar et al. (2016) menjelaskan terjadi coral bleaching disemua stasiun penelitian dengan kategori pemutihan sedikit sampai sedang. Setiawan et al. (2017) menyatakan bahwa dampak pemutihan terumbu karang tahun 2016 di TWP Gili Matra, kondisi tutupan karang menurun dari $23,43 \%$ (tahun 2012) menjadi 18,48\% (tahun 2016). Wouthuyzen et al. (2020) juga meneliti dampak pemutihan karang tahun 2016 di TWP Pieh bahwa tutupan karang hidup turun dari $41,40 \%$ (tahun 2015) menjadi 28,38\% (tahun 2016). Penelitian yang sama juga dikemukan oleh Ulfah et al. (2018) menjelaskan telah terjadi penurunan tutupan karang keras yang significant sejak tahun 2015 sebesar 52,83\% (kondisi baik), di tahun 2016 sebesar 32,43\% (kondisi sedang) dan berlanjut di tahun 2017 menjadi 22,90\% (kondisi rusak).

Ampou et al. (2017) menjelaskan, tanda-tanda coral bleaching pertama terlihat di bulan April 2016. El Nino tealh muncul dan mempunyai berdampak pada terumbu karang Indonesia sejak 2015. Pada bulan bulan September 2015, menunjukkan permukaan laut berada pada titik terendah selama 12 tahun terakhir mempengaruhi kehidupan karang di perairan laut. Studi kasus di perairan Pulau Bunaken menunjukkan tingkat kematian karang yang tinggi sebesar $85 \%$ yang didominasi oleh karang Porites, Heliopora dan Goniastrea. Manikandan et al. (2016) telah meneliti coral bleaching dan pola pemulihan karang di Palk Bay, India. Hasil penelitian menunjukkan adanya peningkatan suhu permukaan laut dan radiasi aktif photosintetik di tahun 2014 dan tahun 2013. Favites dan Leptastrea spp. lebih sensitif dan menjadi yang pertama memutih. Porites spp. menunjukkan respons terjadi pemutihan yang 
lebih cepat pada suhu permukaan laut naik di atas $30^{\circ} \mathrm{C}$. Proses pemulihan sangat bervariasi, Favia sp dan Favites spp akan pulih dalam kondisi lingkungan di saat Porites spp masih terus memutih.

Penelitian Mutmainah dan Clara (2017) bahwa terumbu karang paling rentang terhadap bleaching adalah Acropora sp. Penelitian Muttaqin et al. (2014) bahwa karang keras yang sangat rentan kematian karena coral bleaching adalah Acropora, Pocillopora, Seriatopora dan Stylophora dan tersisa kurang dari $5 \%$ di perairan Utara Aceh. Penelitian yang lain oleh Rudi (2012) di perairan Natuna Bagian Selatan bahwa genus Acropora dan Porites banyak mengalami pemutihan pada tahun 2010.

Komponen bentik yang digunakan untuk menghitung indeks kesehatan terumbu karang adalah fleshy seaweed (makro alga), pecahan karang mati (rubble) dan tutupan karang hidup ( Tabel 6 ). Persentase tutupan karang hidup berdasarkan kategori LIPI (Giyanto et al., 2017a) menunjukkan persen tutupan karang hidup di TWP Selat Bunga Laut pada kategori rendah sampai tinggi. Kategori sedang pada stasiun MTWCO1 dan kategori tinggi pada stasiun MTWC05 dan MTWC07.

Resiliensi merupakan respon ekosistem dan jaminan terhadap terjadinya perubahan lingkungan, dan telah menjadi tujuan utama dari pengelolaan terumbu karang (Nystrom dan Folke, 2001). Tingkat resiliensi (pemulihan terumbu karang) di TWP Selat Bunga Laut dalam kategori tinggi (Tabel 6). Rata-rata tutupan Fleshy Seaweed berkisar antara 0.00$1.47 \%$, kecuali di stasiun MTWC05 sebesar $12.87 \%$. Persen tutupan pecahan karang mati rata-rata sebesar $1.73-51.87 \%$. Persen tutupan karang hidup berkisar antara 1.40- 44.13\%. Berdasarkan Buku Panduan Indeks Kesehatan Karang Indonesia (Giyanto et al,. 2017a) bahwa resiliensi terumbu karang tinggi apabila (tutupan fleshy seaweed $<3 \%$ ) atau (tutupan pecahan karang $\leq 60 \%$ dan tutupan karang hidup $>5 \%$ ). Makro alga dapat mengambil alih karang jika perairan subur dan banyaknya cahaya matahari. Meningkatnya pertumbuhan makro alga memberikan indikasi ancaman terhadap pertumbuhan karang. Makro alga yang tumbuh pada karang dapat membunuh jaringan karang. Makro alga dapat tumbuh pada karang yang hidup dan karang yang mati. Penelitian Luthfi dan Januarsa (2018) bahwa makro alga termasuk organisme kompetitor karang di perairan Pantai Putri Menjangan, Buleleng Bali dengan jenis adalah Caulerpa racemosa, Dictyota dichotama dan Padina autralis. Penelitian Zubia et al. (2018) bahwa makro alga juga dapat digunakan sebagai indikator ekologi terumbu karang. Peningkatan tutupan alga merah (Gelidiella acerosa) terdapat pada stasiun dengan tinggi konsentrasi nitrogen anorganik terlarut.

Tabel 5. Komponen Bentik Terumbu Karang dan Substrat Dasar di Stasiun Penelitian

\begin{tabular}{|c|c|c|c|c|c|c|c|c|c|c|}
\hline Komponen Bentik & $\begin{array}{l}\text { MTW } \\
\text { COl }\end{array}$ & $\begin{array}{l}\text { MTW } \\
\text { C02 }\end{array}$ & $\begin{array}{l}\text { MTW } \\
\text { C03 }\end{array}$ & $\begin{array}{l}\text { MTW } \\
\text { C04 }\end{array}$ & $\begin{array}{l}\text { MTW } \\
\text { C05 }\end{array}$ & $\begin{array}{l}\text { MTW } \\
\text { C06 }\end{array}$ & $\begin{array}{l}\text { MTW } \\
\text { C07 }\end{array}$ & $\begin{array}{l}\text { MTW } \\
\text { C08 }\end{array}$ & $\begin{array}{l}\text { MTW } \\
\text { C09 }\end{array}$ & $\begin{array}{l}\text { Rata- } \\
\text { rata }\end{array}$ \\
\hline Hard Coral $(\mathrm{HC})$ & 28.67 & 2.13 & 2.40 & 2.67 & 44.13 & 6.00 & 44.68 & 1.40 & 1.73 & \multirow{2}{*}{$\begin{array}{c}14.87 \\
0.01\end{array}$} \\
\hline $\begin{array}{l}\text { Recent Dead } \\
\text { Coral (DC) }\end{array}$ & 0.07 & 0.00 & 0.00 & 0.00 & 0.00 & 0.00 & 0.00 & 0.07 & 0.00 & \\
\hline $\begin{array}{l}\text { Dead Coral with } \\
\text { Algae (DCA) }\end{array}$ & 21.47 & 3 & 72.67 & 21.80 & 7 & 36.07 & 39.50 & 46.67 & 23.13 & 38.19 \\
\hline $\begin{array}{l}\text { Soft Coral (SC) } \\
\text { Sponge (SP) }\end{array}$ & $\begin{array}{l}0.00 \\
14.33\end{array}$ & $\begin{array}{c}0.20 \\
11.13\end{array}$ & $\begin{array}{l}0.07 \\
0.60\end{array}$ & $\begin{array}{c}0.13 \\
21.53\end{array}$ & $\begin{array}{l}2.20 \\
4.13\end{array}$ & $\begin{array}{l}0.00 \\
0.00\end{array}$ & $\begin{array}{l}0.00 \\
0.00\end{array}$ & $\begin{array}{l}0.00 \\
0.33\end{array}$ & $\begin{array}{l}0.00 \\
3.07\end{array}$ & \multirow{2}{*}{$\begin{array}{l}0.20 \\
6.13 \\
2.07\end{array}$} \\
\hline $\begin{array}{l}\text { Fleshy Seaweed } \\
\text { (FS) }\end{array}$ & 1.47 & 0 & 0.87 & 0. & 12.87 & 0.00 & 3.00 & 0.13 & 0.27 & \\
\hline Other Biota (OT) & $\begin{array}{l}0.47 \\
13.33\end{array}$ & $\begin{array}{l}5.80 \\
9.73\end{array}$ & $\begin{array}{l}8.80 \\
13.67\end{array}$ & $\begin{array}{c}0.13 \\
29.27\end{array}$ & $\begin{array}{l}7.60 \\
1.73\end{array}$ & $\begin{array}{c}0.33 \\
51.87\end{array}$ & $\begin{array}{c}0.00 \\
11.88\end{array}$ & $\begin{array}{c}2.13 \\
24.53\end{array}$ & $\begin{array}{c}3.07 \\
39.40\end{array}$ & $\begin{array}{l}3.15 \\
21.71\end{array}$ \\
\hline & 20.20 & 15.87 & 0.93 & 24.07 & 0.00 & 5.73 & 0.00 & 24.73 & 29.33 & 13.43 \\
\hline Silt (SI) & 0.00 & 0.00 & 0.00 & 0.40 & 0.07 & 0.00 & 0.95 & 0.00 & 0.00 & 0.16 \\
\hline
\end{tabular}

Keterangan: Hard Coral $(\mathrm{HC})=$ Tutupan karang hidup 
Pemulihan terumbu karang di kawasan Konservasi Pulau Pasi Gusung, Kabupaten Selayar menunjukkan nilai pemulihan semakin naik dalam posisi kondisi sedang. Nilai indeks resiliensi meningkat dari 3.21 menjadi 3.70 dalam kurun waktu tahun 2018-2018 (Kusumo et al., 2019).

Dari 9 stasiun penelitian ditemukan total sebanyak 84 jenis ikan karang. Ikan Coralivora (Chaetodontidae) 18 jenis, ikan Herbivora sebanyak 39 jenis (Acanthuridae sebanyak 20 jenis, Scaridae sebanyak 13 jenis dan Siganidae sebanyak 6 jenis) dan Ikan Carnivora sebanyak 27 jenis (Haemulidae sebanyak 3 jenis, Lethrinidae sebanyak 5 jenis, Lutjanidae sebanyak 6 jenis dan Serranidae sebanyak 13 jenis). Kelimpahan tertinggi ikan Chaetodontidae oleh jenis Chaetodon trifasciatus (70 individu/ $350 \mathrm{~m}^{2}$ ), kelimpahan tertinggi ikan herbivora diwakili oleh jenis Ctenochaetus striatus sebanyak (1 17 individu/ $350 \mathrm{~m}^{2}$ ), dan ikan carnivora diwakili oleh Lutjanus decussatus (22 individu/ $\mathrm{m}^{2}$ ).

Ikan herbivora adalah pengontrol pertumbuhan alga di ekosistem terumbu karang. Penelitian di perairan Kabupaten Natuna oleh Damhudy et al. (2011) bahwa kelimpahan ikan herbivora, dan rata-rata tutupan tutupan karang hidup yang tinggi akan menurunkan tutupan alga di perairan. Jenis ikan herbivora yang berperan menjaga ekosistem karang adalah Chlorurus microrhinos, scarus rivulatus dan Siganus doliatus.
Penelitian Setiawan et al. (2017) terjadi penurunan biomassa ikan di TWP Gili Matra setelah pemutihan karang tahun 2016 dimana biomassa ikan 28.733,26 individu/ha (tahun 2012) menjadi $11.431,18$ individu/ha. Penurunan kelimpahan dan biomassa ikan terjadi pada ikan herbivora. Muttaqin et al. (2014) menemukan terjadi penurunan populasi ikan pemakan polip karang secara nyata pasca peristiwa coral bleaching tahun 2010 di perairan Utara Aceh.

Penelitian Munga et al. (2012) meneliti status komunitas ikan terumbu karang di dalam kawasan Konservasi Laut Mombasa, Kenya, lebih satu dekade setelah pendiriannya. Hasil menunjukkan perbedaan komposisi ikan di dalam Kawasan Konservasi Laut adalah karena yang lebih besar kelimpahan Haemulidae (karnivora nokturnal) dan Acanthuridae (herbivora) di daerah yang tidak dilarang ambil ikan daripada di kawasan yang sebagian terlindungi.

Total biomassa ikan karang yang diteliti adalah biomassa ikan target yaitu ikan herbivora dan ikan carnivora. Berdasarkan kategori kelimpahan ikan karang LIPI (Giyanto et al., 2017a) termasuk kategori rendah dengan rata-rata $<970 \mathrm{~kg} / \mathrm{ha}$. Biomassa ikan target berkisar antara 8.93-253.25 kg/ha. Biomassa ikan karang bernilai kecil karena kejadian coral bleaching di sebagian besar Samudra Hindia tahun 2016 dan maraknya penangkapan ikan karang dilokasi ini (Tabel 7).

Tabel 6. Komponen Bentik Terumbu Karang dan Kategorinya

\begin{tabular}{lccccccc}
\hline Stasiun & Lintang & Bujur & $\begin{array}{c}\text { Fleshy } \\
\text { Seaweed } \\
\text { (FS) }\end{array}$ & $\begin{array}{c}\text { Pecahan } \\
\text { Karang } \\
\text { mati } \\
\text { (Rubbel) }\end{array}$ & $\begin{array}{c}\text { Tutupan } \\
\text { Karang } \\
\text { Hidup } \\
(\mathrm{HC})\end{array}$ & $\begin{array}{c}\text { Kategori } \\
\text { Tutupan } \\
\text { Karang }\end{array}$ & $\begin{array}{c}\text { Kategori } \\
\text { Resiliensi } \\
\text { (Pemulihan) }\end{array}$ \\
\hline MTWC01 & -2.002140 & 99.574810 & 1.47 & 13.33 & 28.67 & Sedang & Tinggi \\
MTWC02 & -2.025000 & 99.577800 & 0.00 & 9.73 & 2.13 & Rendah & Tinggi \\
MTWC03 & -1.980930 & 99.599670 & 0.87 & 13.67 & 2.40 & Rendah & Tinggi \\
MTWC04 & -2.143220 & 99.541280 & 0.00 & 29.27 & 2.67 & Rendah & Tinggi \\
MTWC05 & -2.133000 & 99.537000 & 12.87 & 1.73 & 44.13 & Tinggi & Tinggi \\
MTWC06 & -1.695770 & 99.301100 & 0.00 & 51.87 & 6.00 & Rendah & Tinggi \\
MTWC07 & -1.750850 & 99.270220 & 3.00 & 11.88 & 44.68 & Tinggi & Tinggi \\
MTWC08 & -1.811120 & 99.291500 & 0.13 & 24.53 & 1.40 & Rendah & Tinggi \\
MTWC09 & -1.872130 & 99.285520 & 0.27 & 39.40 & 1.73 & Rendah & Tinggi \\
\hline
\end{tabular}


Tabel 7. Total Biomassa Ikan Karang

\begin{tabular}{lrc}
\hline Stasiun & Total Biomassa $(\mathrm{kg} / \mathrm{ha})$ & Kategori Biomassa lkan karang \\
\hline MTWC01 & 286.69 & Rendah \\
MTWC02 & 251.72 & Rendah \\
MTWC03 & 424.35 & Rendah \\
MTWC04 & 80.24 & Rendah \\
MTWC05 & 128.68 & Rendah \\
MTWC06 & 231.67 & Rendah \\
MTWC07 & 8.93 & Rendah \\
MTWC08 & 186.59 & Rendah \\
MTWC09 & 253.25 & Rendah \\
\hline
\end{tabular}

Tabel 8. Nilai Indeks Kesehatan Terumbu Karang

\begin{tabular}{lllclcc}
\hline Stasiun & $\begin{array}{c}\text { Tutupan } \\
\text { Karang Hidup }\end{array}$ & Resiliensi & $\begin{array}{c}\text { Nilai } \\
\text { Karang }\end{array}$ & $\begin{array}{c}\text { Total Biomasa } \\
\text { lkan }\end{array}$ & $\begin{array}{c}\text { Nilai } \\
\text { lkan }\end{array}$ & $\begin{array}{c}\text { Indeks Kesehatan } \\
\text { Karang }\end{array}$ \\
\hline MTWC01 & Sedang & Tinggi & 5 & Rendah & 2 & 5 \\
MTWC02 & Rendah & Tinggi & 3 & Rendah & 2 & 3 \\
MTWC03 & Rendah & Tinggi & 3 & Rendah & 2 & 3 \\
MTWC04 & Rendah & Tinggi & 3 & Rendah & 2 & 3 \\
MTWC05 & Tinggi & Tinggi & 6 & Rendah & 2 & 6 \\
MTWC06 & Rendah & Tinggi & 3 & Rendah & 2 & 3 \\
MTWC07 & Tinggi & Tinggi & 6 & Rendah & 2 & 6 \\
MTWC08 & Rendah & Tinggi & 3 & Rendah & 2 & 3 \\
MTWC09 & Rendah & Tinggi & 3 & Rendah & 2 & 3 \\
\hline
\end{tabular}

Indeks kesehatan terumbu karang bernilai 3-6. Indeks kesehatan terumbu karang bernilai 3 terdapat di 6 stasiun yaitu stasiun perairan Pulau Hawera, perairan Pulau Siburu, perairan Pukarayat, perairan Masilok, perairan Pulau Nayangnyang dan perairan Pulau Botik. Nilai indeks kesehatan karang bernilai 5 pada stasiun perairan Pulau simakakang. Nilai indeks kesehatan karang bernilai 6 terdapat pada stasiun perairan Pulau Pitojat Besar dan perairan Malilimok. Indeks kesehatan karang didominasi oleh nilai 3 dengan ditunjukkan persen tutupan karang hidup yang rendah, tingkat resiliensi yang tinggi dan biomassa ikan yang rendah. Indeks kesehatan karang nilai 5 ditunjukkan oleh persen tutupan karang hidup yang sedang, tingkat resiliensi yang tinggi dan biomassa ikan yang rendah. Nilai indeks kesehatan karang 6 ditunjukkan oleh persen tutupan karang hidup yang tinggi, tingkat resiliensi yang tinggi dan biomassa ikan karang yang rendah. Berdasarkan data (Tabel 8, Gambar 1 dan Gambar 2) sebanyak $67 \%$ stasiun penelitian mempunyai indeks kesehatan karang skala 3.

Berdasarkan penelitian Suparno dan Efendi (2018) bahwa indeks kesehatan terumbu karang di perairan Pulau Sipora Utara dan perairan Siberut Barat Daya dengan nilai antara 1-6. Dari 9 stasiun penelitian nilai indeks kesehatan karang 1 sebanyak 1 stasiun, nilai 3 sebanyak 5 stasiun, nilai 5 sebanyak 2 stasiun dan nilai 6 sebanyak 2 stasiun. Nilai 3 merupakan nilai indeks kesehatan terumbu karang yang dominan. Indeks kesehatan terumbu karang benilai 1 pada stasiun perairan Pulau Simakakang. Diaz-Perez et al. 


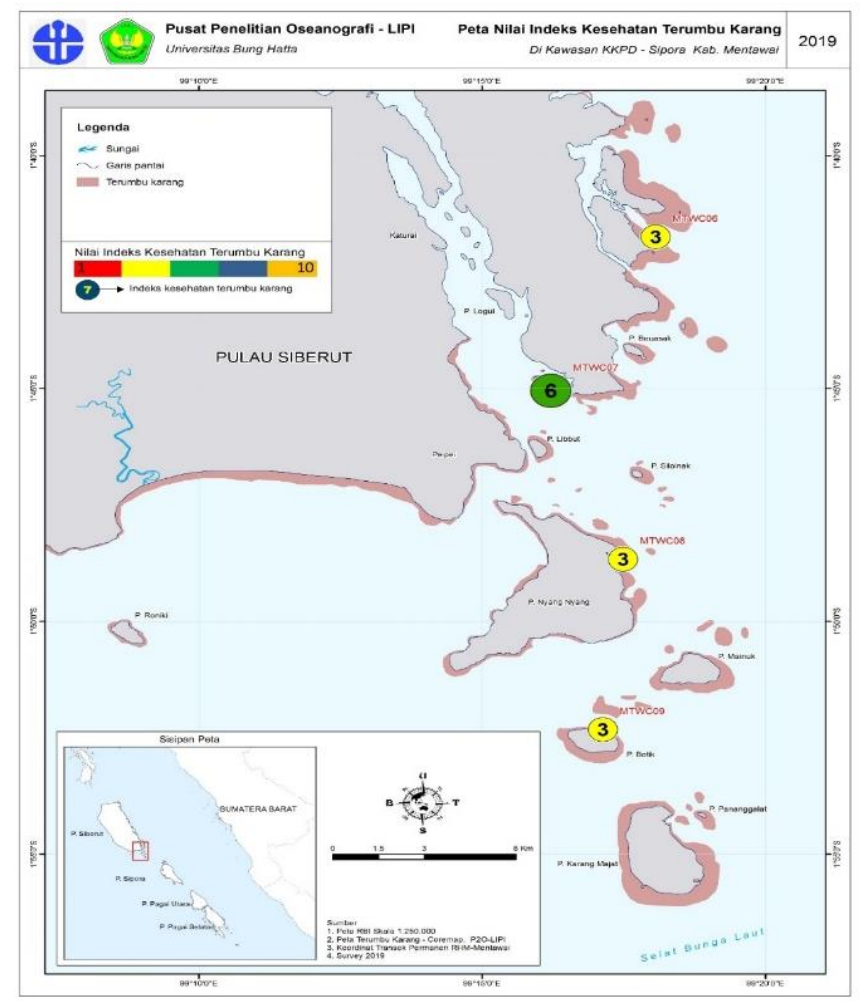

Gambar 1. Peta Indeks Kesehatan Terumbu Karang di Perairan Pulau Siberut

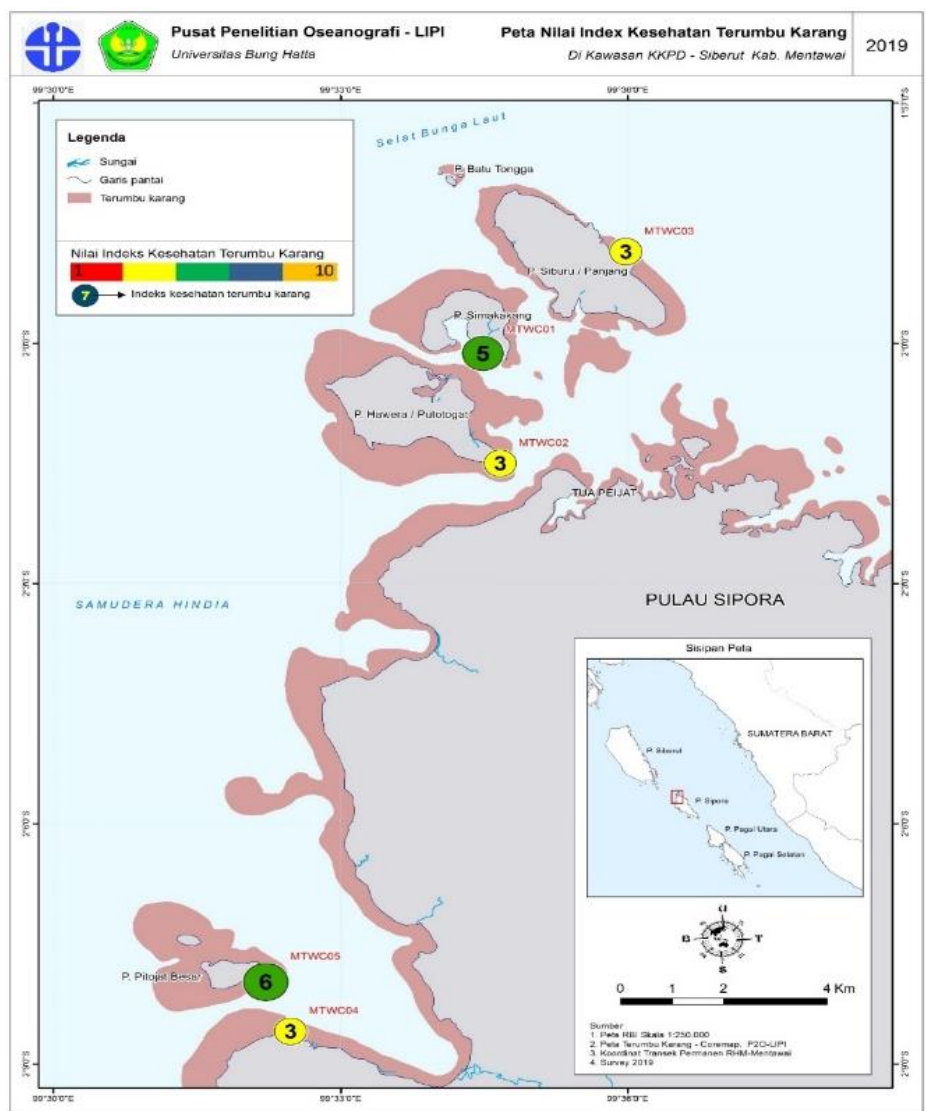

Gambar 2. Peta Indeks Kesehatan Terumbu Karang di Perairan Pulau Sipora 
(2016) meneliti kawasan perairan laut Karibia bagian barat dengan mengupas Coral Reef Index (CRI) dan two-dimensional Coral Health Index (2D-CHI). CRI dengan parameter benthos, ikan dan mikroba, sedangkan 2D-CHI dengan parameter ikan dan benthos. Hasil kajian CRI bahwa 57,15\% kawasan dengan nilai indeks kesehatan karang buruk dan 42,85\% kawasan dengan nilai kritis. Berdasarkan 2D-CHI bahwa 28,50\% kawasan dengan kategori terdegradasi dan $71,15 \%$ kawasan sangat terdegradasi. Dari Hasil RHI ada korelasi yang kuat antara kesehatan karang dengan kelimpahan ikan karang. Tidak ada keterkaitan antara indeks kesehatan karang dengan keaneragaman karang di lokasi penelitian.

\section{KESIMPULAN}

Kesimpulan hasil penelitian yang telah dilakukan bahwa persen rata-rata tutupan karang hidup dengan nilai $1.40-44.68 \%$, fleshy seaweed $0.13 \%$ - $12.87 \%$, pecahan karang $1.73-39.40 \%$, dan rata-rata total biomassa ikan karang berkisar 8.93 - $253.23 \mathrm{~kg} / \mathrm{ha}$. Indeks kesehatan terumbu karang dengan nilai 3-6. Enam puluh tuju persen (67\%) stasiun penelitian yang diteliti mempunyai indeks kesehatan terumbu karang sebesar 3. Nilai indeks kesehatan karang skala 3 ditunjukkan oleh persen tutupan karang hidup yang rendah, tingkat resiliensi yang tinggi dan nilai biomassa ikan yang rendah.

\section{UCAPAN TERIMA KASIH}

Atas bantuan dana penelitian dan dukungan sumberdaya manusia dari Pusat Penelitian Oseanografi LIPI dan Coremap CTI, Penulis mengucapkan terima kasih yang sebesar-besarnya.

\section{DAFTAR PUSTAKA}

Abrar, M. 2015. Monitoring kondisi Terumbu Karang dan ekosistem terkait, di Taman Wisata Perairan (TWP) Selat Bunga Laut, Kabupaten Kepulauan Mentawai, Sumatera Barat. Jakarta: Coremap CTI, Pusat Penelitian Oseanografi LIPI.

Abrar, M. 2016. Monitoring kondisi Terumbu Karang dan ekosistem terkait, di Taman Wisata Perairan (TWP) Selat Bunga Laut,
Kabupaten Kepulauan Mentawai, Sumatera Barat. Jakarta: Coremap CTI, Pusat Penelitian Oseanografi LIPI.

Ampou, E.E., Johan, O., Menkes, C.E., Nino, F., Birol F., Ouillon S. \& Andrefovet, S. 2017. Coral Mortality Induced by the 2015-2016 El-Nino in Indonesia:the Effect of Rapid Sea Level Fall. Biogeosciences 14:817-826. doi : $10.5194 / \mathrm{bg}-14-817-2017$

Damhudy, D., Kamal, M.M. \& Ernawati, Y. 2011. Kondisi Kesehatan Terumbu Karang Berdasarkan Kelimpahan Ikan Herbivora di Kecamatan Pulau Tiga, Kabupaten Natuna. Jurnal IImu-IImu Perairan dan Perikanan Indonesia 17:215-225.

Diaz-Perez, L., Rodriguez-Zaragoza, F.A., Ortiz, M., Cupul-Magana, A.L.,Carriquiry, J.D., Rios-Jara, E., Rodri-Guez-Troncoso \& Garcia-Rivas, M.D.C. 2016. Coral Reef Health Indices versus the Biological, Ecological and Functional Diversity of Fish and Coral Assemblages in the Caribbean Sea. PLOS ONE 11:1-19. doi : 10.1371/journal.pone.0161812

Giyanto, Mumby, P, Dhewani, N, Abrar, M. \& Iswari, M.Y. 2017a. Indeks Kesehatan Terumbu Karang Indonesia. Jakarta: Coremap CTI Pusat Penelitian Oseanografi, LIPI.

Giyanto, Abrar, M, Manuputty, A.E.W., Siringongo, R.M., Tuti, Y. \& Zulfianita, D. 2017b. Panduan Pemantauan Kesehatan Terumbu Karang. Jakarta: Coremap CTI Pusat Penelitian Oseanografi, LIPI.

Kusumo, S, Adrianto, L., Boer, M., \& Suharsono. 2019. Indeks Resiliensi Terumbu Karang dengan Pendekatan Sistem Sosial Ekologi: Studi Kasus KKPD Pulo Pasi Gusung, Selayar. Journal of Fisheries and Marines Research, 3:227-235. doi : 10.21776/ub. jfmr.2019.003.02.13

Luthfi, O.M. \& Januarsa, I.H. 2018. Identifikasi Organisme Kompetitor Terumbu Karang di Perairan Pantai Putri Menjangan, Buleleng Bali. Jurnal Kelautan, 11:24-30. doi : 10.21 107/jk.v1 1il.2073

Manikandan, B. Ravindran, J., Vidya, P.J. \& Murali, R M. 2016. Bleaching and Recovery Patterns of Corals in Palk Bay, India: An Indication of Bleaching Resilient Reef. Regional Studies in Marine Science 8:151158. doi : 10.1007/s11356-017-8772-4

Munga, CN., Guebas, F.D., Mohame, M.O.S, Obura, D.O., Amiyo, N. and Vanreusel, A., 
2012. Status of Coral Reef Fish Communities within the Mombasa Marine Protected Area, Kenya, more than a Decade after Establishment. Western Indian Ocean Journal of Marine Science, 10:169-184.

Muttaqin, M., Kamal, M.M., Haryadi, S., Pardede, S., Tarigan, S., \& Campbell, S. 2014. Dampak Pemutihan Karang terhadap Ekosistem Terumbu Karang pada Tahun 2010 di Perairan Utara Aceh. Jurnal IImu dan Teknologi Kelautan Tropis 1:15-21. doi : 10.29244/Jitkt.v8i2

Nystrom, N \& Folke, C. 2001. Spatial Resilience of Coral Reefs. Ecosystems, 4:406-417.

Rudi, E. 2012. Pemulihan Karang di Perairan Natuna Bagian Selatan Tahun 2010. Biospecies, 5:1-7.

Setiawan, F, Muttaqin, A., Tarigan, S.A., Muhidi, Hotmariyah, Sabil, A., \& Pinkan, J. 2017. Dampak Pemutihan Karang Tahun 2016 Terhadap Ekosistem Terumbu Karang: Studi Kasus di TWP Gili Matra (Gili Air, Gili Meno dan Gili Trawangan) Provinsi NTB. Jurnal Kelautan, 10:147-161. doi : 10.211 $07 / j k . v 10 i 2.2878$

Siringoringo, RM. 2014. Monitoring kondisi Terumbu Karang dan ekosistem terkait, di Taman Wisata Perairan (TWP) Selat Bunga Laut, Kabupaten Kepulauan Mentawai, Sumatera Barat. Jakarta: Pusat Penelitian Oseanografi, LIPI.

Suhartini, S,R, Wibowo, K, Edrus, I.N, \& Fahmi. 2017. Panduan Pemantauan Ikan
Terumbu Karang. Jakarta: Coremap CTI Pusat Penelitian Oseanografi, LIPI.

Suparno \& Efendi, Y. 2018. Monitoring kondisi Terumbu Karang dan ekosistem terkait, di Taman Wisata Perairan (TWP) Selat Bunga Laut, Kabupaten Kepulauan Mentawai, Sumatera Barat. Jakarta: Coremap CTI Pusat Penelitian Oseanografi, LIPI.

Ulfah, M., Yolanda, C., Karina, S., Purnawan, S., \& Agustina, S. 2018. Perbandingan Tutupan Karang Keras Sebelum, Saat dan Sesuah Pemutihan Karang di Perairan Krueng Raya, Aceh Besar. Jurnal Ilmu dan Teknologi Kelautan Tropis, 10:739-745. doi: 10.29244/jitkt.v10i3.21974

Wouthuyzen, S., Abrar. M.. Corvianawatie, C., Kusumo, S., Yanuar, Y., Darmawan, Yennafri, Salatalohi, A., Hanif, A., Permana, S., \& Arafat, M.Y. 2020. Kecenderungan Naiknya Suhu Permukaan Laut dan Resiliensi Karang Setelah Kejadian Pemutihan Karang 2010 dan 2016 di Taman Wisata Perairan (TWP) Pulau Pieh, Padang, Sumatera Barat. Oseanologi dan Limnologi di Indonesia, 5:1-18. doi : 10.14203/oldi.2020.v5i1.236

Zubia, M., Depetris, M., Flores, O., Turquet, J., \& Cuet, P. 2018. Macroalgae as a Tool for Assessing the Ecological Status of Coral Reefs under the Water Framework Directive: A Case Study on Reef Flats of La Reunion (Indian Ocean). Marine Pollution Bulletin 137:339-351. doi : 10/1016/j.mar polbul.2018.10.029 